\title{
The Relationship Between C-Reactive Protein Level, Disease Severity and Psoriatic Arthritis in Psoriasis Patients
}

\author{
Psoriasis Hastalarında C-Reaktif Protein Düzeyinin Hastalık Şiddeti ve Psoriatik Artrit İle İlişkisi
}

Şirin Çelik ${ }^{1}$ (D) Nahide Onsun², (D) Alkım Ünal Çakıter ${ }^{3}$, (D) Özlem Su Küçük ${ }^{2}$, (D) Aylin Rezvani ${ }^{4}$

1-Yeniyüzyıl Üniversitesi Özel Gaziosmanpaşa Hastanesi Dermatoloji ABD, 2- Bezmialem Vakıf Üniversitesi Hastanesi Dermatoloji,

3- İstanbul Medipol Üniversitesi Hastanesi Dermatoloji, 4- Medipol Üniversitesi Tıp Fakültesi Fiziksel Tıp ve Rehabilitasyon Anabilim Dalı

\begin{abstract}
Objective: This study aimed to determine the relationship between C-reactive protein psoriasis and psoriatic arthritis, which are in the group of Immune-Mediated Inflammatory Disease.

Materials and Methods: 201 psoriasis patients with or without psoriatic arthritis aged between 18-70 years and 98 healthy individuals aged between 18-70 years were included in the study. Psoriasis severity was calculated by psoriasis severity index, concurrent serum C-reactive protein level (by immunoturbidimetric latex method) was evaluated, and patients were evaluated for psoriatic arthritis in physical therapy and rehabilitation clinic. C-reactive protein levels between groups were compared. Correlation between Creactive protein level and psoriasis severity index was evaluated in psoriasis patients.

Results: C-reactive protein levels were higher in psoriasis patients than the normal population $(p<0.001)$, but there was no correlation between C-reactive protein level and psoriasis severity. C-reactive protein levels were higher in patients with active psoriatic arthritis compared to the control group $(p<0.001)$ and psoriasis patients $(p<0.001)$. In terms of $C$-reactive protein level values, no statistically significant difference was found between active psoriatic arthritis patients and inactive psoriatic arthritis patients $(p=0.449)$.

Conclusion: Although C-reactive protein level is higher in psoriasis patients compared to normal population, it is not correlated with disease severity, and therefore it is not useful to use psoriasis in the follow-up; however, we think that C-reactive protein level may be used in follow-up for psoriatic arthritis development in psoriasis patients. The fact that C-reactive protein level was not significantly different in active and inactive psoriatic arthritis patients, C-reactive protein level is not a sufficient indicator to assess whether psoriatic arthritis is active or inactive.

ÖZET

Amaç: Bu çalıșmada "Immune Mediated Inflammatory Disease (Immmün Aracıl İltihabi Hastalı)" grubuna dâhil olan psoriasis ve psoriatik artritte, C-reaktif proteinin psoriasis şiddeti ve psoriatik artrit ile ilişkisini tespit etmek amaçlandl.

Gereç ve Yöntem: Çalı̧̧maya 18-70 yaş arası psoriatik artriti olan veya olmayan toplam 201 psoriasis hastast ve kontrol grubu olarak 18-70 yaş arast 98 sağlıklı birey alındl. Psoriasis şiddeti psoriasis alan şiddet indeksi ile hesaplandı ve eşzamanlı serum C-Reaktif Protein düzeyi (immunoturbidimetric latex yöntemi ile) baknlip hastalar fizik tedavi ve rehabilitasyon kliniǧinde psoriatik artrit yönünden değerlendirildi. Gruplar arası C-Reaktif Protein düzeyleri karşılaştırıldı. Psoriasis hastalarında C-Reaktif Protein düzeyi ve psoriasis alan şiddet indeksi korelasyonuna bakzldl.

Bulgular: C-Reaktif Protein düzeyinin, psoriasis hastalarinda normal popülasyona göre yüksek olduğu $(p<0,001)$ ancak psoriasis şiddeti arasinda korelasyon olmadiğ saptandı $(p=0,093)$. C-Reaktif Protein değerleri, aktif psoriatik artrit hastalarında kontrol grubuna $(p<0,001)$ ve psoriasis hastalarına $(p<0,001)$ göre yüksek bulundu. C-Reaktif Protein değerleri açısından aktif psoriatik artrit hastaları ile inaktif psoriatik artrit hastaları arasinda istatistiksel olarak anlamlı fark bulunmadı $(p=0,449)$.

Sonuç: C-Reaktif Protein'in psoriasis hastalarında normal insanlara göre yüksek olmasına rağmen, hastalık şiddetiyle korele olmadığından, psoriasis şiddeti takibinde kullanımının yararlı olmayacağl; ancak psoriasis hastalarında psoriatik artrit gelișimi açısından takipte kullanılanılabileceğini düşünmekteyiz. Aktif ve inaktif psoriatik artrit hastalarında C-Reaktif Protein düzeyi açısından anlamlı fark saptanmaması, psoriatik artritin aktif veya inaktif dönemde olduğunu değerlendirmede tek başına yeterli bir belirteç olmadlăg sonucunu doğurmaktadır.
\end{abstract}

Key Words:

Psoriasis,

Psoriasis severity index,

Psoriatic arthritis,

C-reactive protein level
Anahtar Kelimeler:
Psoriasis,
Psoriasis alan şiddet indeksi,
Psoriatik artrit,
C-Reaktif Protein Seviyesi

\section{GíRiș}

Psoriasis, farklı klinik biçimlerde ortaya çıkabilen, görülme sıklığı \% 1-3 olan, kronik seyirli ve immun aracilı bir hastalıktır (1). Etyopatogenezinde immünolojik, otoimmün ve genetik faktörlerin etkili olduğu düşünülmekle birlikte son yıllarda, 'Immune Mediated Inflammatory Disease' (IMID) olarak tanımlanan kronik iltihabi hastalıklar grubuna dâhil edilmektedir (1). Psoriatik artrit ise; psoriasisin eşlik ettiği, çevresel ve/veya merkezi iskeletin müzmin iltihabi artritidir ve IMID grubuna dâhil edilen hastalıklar arasındadır.

Psoriasisde cildin dermis ve epidermis katmanlarında bariz iltihabi değişiklikler meydana gelir. Özellikle 


\section{Çelik et al.}

hastalığın aktif seyrinde nötrofil ağırlıklı hücre birikimi vardır. Nötrofillerin uyarılması ile serbest radikal oluşumu, bazı enzimlerin ortama salınması ve degranülasyon gibi olaylar başlatılır (2). Bunun sonucunda TNF- $\alpha$ ve interlökin 6 salgılanması artar ve takiben C-reaktif protein (CRP) salınımı artar (3). CRP enfeksiyon kaynaklı veya olmayan iltihabi reaksiyonun en hassas belirteci olarak kabul edilir ve serum seviyesi doku hasarı sonrasında ilk 24 saatte normalin 1000 kat fazlasına kadar yükselebilir ancak uygun tedavi ile birkaç gün içinde normal seviyelere düşer $(4,5)$.

$\mathrm{Bu}$ çalışmada "Immune Mediated Inflammatory Disease (IMID)" (İmmün Aracılı İltihabi Hastalık) grubuna dâhil olan psoriasis ve psoriatik artritte, iltihabi yanıtın en duyarlı belirteci olan C-reaktif proteinin psoriasis şiddeti ve psoriatik artrit ile ilişkisini tespit etmek ve CRP'nin bu hastalıkların takibinde biz hekimlere yardımcı olup olamayacağını belirlemek amaçlandı.

\section{GEREÇ ve YÖNTEM}

Çalışmaya Bezmialen Vakıf Üniversitesi Tıp Fakültesi klinik araştırmalar etik kurulundan 09.06.2011 tarih ve 8/2 karar nosu ile onay alındıktan sonra başlandı. Çalışmaya 18-70 yaş arası psoriatik artriti olan veya olmayan toplam 201 psoriasis hastası ve kontrol grubu olarak 18-70 yaş arası 98 sağlıklı birey alındı. 201 psoriasis hastasının psoriasis alan şiddet indeksi (PAŞİ) hesaplandı ve eşzamanlı serum C-Reaktif Protein düzeylerine (immunoturbidimetric latex yöntemi ile) bakılıp hastalar fizik tedavi ve rehabilitasyon (FTR) kliniğinde psoriatik artrit yönünden değerlendirildi. Artriti saptanmayan hastalar psoriasis hasta grubuna ( $n=128)$, aktif psoriatik artriti saptanan hastalar aktif psoriatik artrit hasta grubuna $(n=49)$ ve daha önceden psoriatik atriti olup muayene esnasında kliniği inaktif olan hastalar inaktif psoriatik artrit hasta grubuna ( $n=24)$ dâhil edildi.

CRP'nin psoriasis şiddeti ile ilişkisinin değerlendirilmesi için psoriasis hastalarının $(n=128)$ CRP düzeyi kontrol grubunun ( $n=98)$ CRP düzeyi ile karşılaştırıldı ve aynı hastalarda CRP ve PAŞI korelasyonuna bakıldı. Ayrıca kontrol grubu dışındaki tüm hastalar $(n=201)$ ile aktif psoriatik artrit $(n=49)$ ve inaktif psoriatik artrit $(n=24)$ hastalarında da CRP ve PAŞI ilişkisine bakıldı. Sistemik tedavilerin CRP düzeyini etkileyebilme ihtimaline karşın sadece bölgesel tedavi alan psoriasis hastalarında da $(n=59)$ CRP ve PAŞİ korelasyonuna bakıldı.

CRP'nin psoriatik artrit ile ilişkisini değerlendirmek için aktif psoriatik artrit hastalarının $(n=49)$ CRP düzeyi kontrol grubu $(\mathrm{n}=98)$, psoriasis hastaları
Hasta gruplarının PAŞİ ve CRP değerleri

\begin{tabular}{llll} 
& $\begin{array}{l}\text { Psoriasis } \\
\text { hastaları } \\
(\mathrm{n}=128)\end{array}$ & $\begin{array}{l}\text { Aktif psoriatik } \\
\text { artrit hastaları } \\
(\mathrm{n}=49)\end{array}$ & $\begin{array}{l}\text { İnaktif } \\
\text { psoriatik } \\
\text { hastalar1 } \\
(\mathrm{n}=24)\end{array}$ \\
\hline Max & 18,6 & 18,2 & 14,1 \\
Min & 0 & 0,2 & 0 \\
Ortalama & 3,13 & 4,81 & 3,43 \\
Std deviasyon & 3,35 & 4,78 & 3,64 \\
Max & 4,4 & 11,4 & 2,9 \\
Min & 0 & 0,01 & 0,01 \\
Ortalama & 0,38 & 1,01 & 0,56 \\
Std deviasyon & 0,64 & 1,84 & 0,63
\end{tabular}

$(\mathrm{n}=128)$ ve inaktif psoriatik artrit hastalarının $(\mathrm{n}=24)$ CRP düzeyi ile karşılaştırıldı. Ayrıca inaktif psoriatik artrit hastalarının CRP düzeyi de aynı şekilde kontrol grubu $(\mathrm{n}=98)$ ve psoriasis hastaları $(\mathrm{n}=128)$ ile karşılaştırıldı.

CRP ve PAŞİ'nin gruplar arasındaki anlamlılıklarına bakmak için Mann-Whitney U testi ve PAŞİ ve CRP korelasyonuna bakmak için Pearson korelasyon testi kullanıldı.

\section{BULGULAR}

Çalışmaya alınan toplam 299 hastanın 128'i psoriasis hastası, 49'u aktif psoriatik artrit hastası, 24'ü inaktif psoriatik artrit hastas1, 98'i kontrol bireyi idi.

Ortalama PAŞİ değeri psoriasis hastalarında 3,13 (0$18,6)$, aktif psoriatik artrit hastalarında $4,81(0,2-18,2)$, inaktif psoriatik artrit hastalarında 3,43 (0-14,1) idi. İstatistiksel olarak gruplar içinde PAŞİ değerleri anlamlı fark göstermemekteydi $(\mathrm{p}=0,177)$. Ortalama CRP değeri psoriasis hastalarında $0,387(0-4,4)$, aktif psoriatik artrit hastalarında $1,01(0,01-11,4)$, inaktif psoriatik artrit hastalarında $0,566(0,01-2,97)$, kontrol grubunda 0,191 (0,001-3,03) idi (Tablo 1).

CRP değerleri psoriasis hastalarında $(n=128)$ kontrol grubuna $(n=98)$ göre ileri derecede anlamlı bir şekilde yüksek bulunmuştur $(\mathrm{p}<0,001)$. Ancak psoriasis hastaları arasında CRP değerleri ile PAŞİ değerleri arasında anlamlı düzeyde bir ilişki bulunmamıştır ( $\mathrm{p}=0,093)$ (Şekil 1).

Psoriasis hastalarına ek olarak aktif psoriatik artrit ve inaktif psoriatik artrit hastalarını da içeren 201 hastanın tamamında hastaların CRP değerleri ile PAŞİ değerleri arasındaki ilişkiye bakılmış ve anlamlı bir ilişki bulunmamıştır ( $\mathrm{p}=0,066)$.

Bölgesel, sistemik ve biyolojik ajan tedavisi alan hastaların almakta olduğu tedavi ile CRP düzeyi arasında anlamlı bir ilişki saptanmamıştır $(p>0,05)$. Ancak yine de bazı çalışmalarda ilaçların CRP düzeyini etkileyebileceği üzerinde durulduğundan sistemik ve biyolojik ajan tedavisi alan hastalar dışlanarak sadece bölgesel tedavi alan psoriasis 
Phnx Med J. July, 2020. Volume 2 No 2

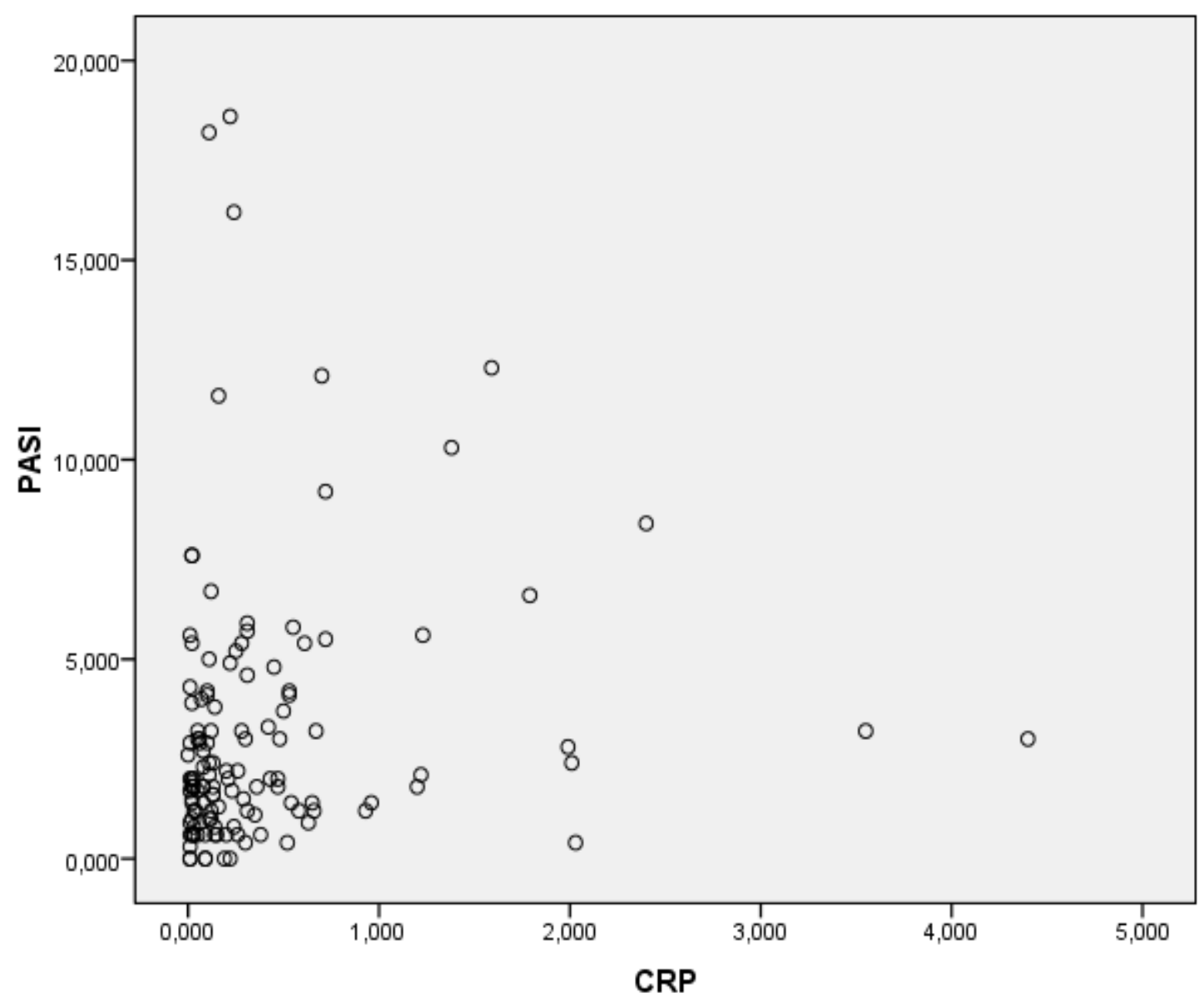

Şekil 1: Psoriasis hastalarında PAŞİ-CRP korelasyonu

hastalarında $(n=59)$ ayrıca PAŞI ve CRP ilişkisine bakılmış ve anlamlı bir ilişki saptanmamıştır $(\mathrm{p}=0,422)$.

CRP'nin psoriatik artrit ile ilişkisine bakıldığında CRP değerleri aktif psoriatik artrit hastalarında kontrol grubuna göre $(p<0,001)$ ve psoriasis hastalarına göre $(p<0,001)$ ileri derecede anlamlı bir şekilde yüksek bulunmuştur. Ancak CRP değerleri açısından aktif psoriatik artrit hastaları ile inaktif psoriatik artrit hastaları arasında anlamlı fark bulunmamıştır $(\mathrm{p}=0,449)$.

İnaktif psoriatik artrit hastalarında kontrol grubuna göre CRP değerleri ileri derecede anlamlı olarak yüksek bulunmuştur $(p<0,001)$. CRP değerleri açısından psoriasis hastaları ile inaktif psoriatik artrit hastaları arasında Bonferroni' ye göre düzeltilmiş anlamlılık sınır açısından anlamlı fark bulunamamıştır ( $p>0,0083$ ), ama basit bivariate yargılama çerçevesinde inaktif psoriatik artritlilerin CRP düzeyi psoriasis grubundan daha yüksek olma görüntüsündedir.

\section{TARTIŞMA}

Psoriasis, immün aracılı mekanizmalarla geliştiği için "Immune Mediated Inflammatory Disease (IMID)" (İmmün Aracılı İltihabi Hastalık) olarak tanımlanan kronik iltihabi bir hastalıktır. Klinik olarak genellikle ciltte keskin sınırlı, eritemli plak veya papüller üzerinde yerleşmiş parlak, sedefi-beyaz kabuklarla karakterizedir (3).

Psoriasisli hastaların yaklaşık 1/3'ünde psoriatik artrit (PsA) gelişir. PsA seronegatif spondiloartropati olarak sınıflandırılmış eklem ve bağ dokusunu etkileyen kronik inflamasyonla giden bir artropati olup psoriasis gibi "Immune Mediated Inflammatory Disease (IMID)" (İmmün Aracılı İnflamatuar Hastalık) grubuna dâhildir (6). Psoriatik artrit değişken klinik özellikler taşır. Psoriatik artritte saptanan bulgular; distal interfalangial (DIP) eklem tutulumu, tırnak tutulumu, daktilit, entezit, osteoliz ve periartiküler yeni kemik oluşumudur $(7,8)$. Psoriatik artrit zaman zaman klinik olarak aktifken zaman zaman remisyon dönemleri olmaktadır. Bizim çalışmaya aldığımız 201 psoriasisli hastada, aktif psoriatik artrit oranı \%16,39 (49 kişi), inaktif psoriatik artrit oranı \%8,03 (24 kişi) idi.

CRP en bilinen akut faz reaktanıdır ve iltihabi durumlarda genellikle bariz olarak yükselir, bu yükselme normalin 1000 kat üzeri seviyelere ulaşabilir. Serum dışında periton sıvısı, plevral, perikardial ve sinovial sıvıda gibi diğer vücut sıvılarında da yüksek düzeyde saptanabilir. İltihabi reaksiyonlarda en geç 18 


\section{Çelik et al.}

ile 24 saatte serum seviyesi yükselir (9-12). Genelde iltihabi cevap ile CRP gibi iltihabi belirteçlerin artış düzeyi paraleledir. Ancak Çeşitli etkenler bunu değiştirebilir. Mesela kronik iltihabi durumların akut ataklarında iltihabi yanıt hastanın kliniğine göre nispeten daha zayıf $(9,12,13)$.

Rocha-Pereira ve arkadaşları psoriasis şiddetlendikçe inflamatuar belirteçlerde de (elastaz, CRP, $\alpha_{2-}$ macroglobulin, $\alpha_{1}$-antitrypsin, tiobarbitürik asit/total plazma antioksidan kapasitesi ve nötrofil) artış olduğunu gözlemlemişlerdir (2). Coimbra ve arkadaşları kontrol grubuna göre psoriasis hastalarında serum CRP düzeyini yüksek bulmuşlardır. Ayrıca tedavi öncesi ve tedavinin 3,6 ve 12 . haftalarında yaptıkları ölçümlerde CRP ve PAŞI'yi korele bulmuşlardır (14). Chodorowska ve arkadaşları psoriasisin aktif döneminde serum CRP düzeyini oldukça yüksek bulmuşlardır. Etkili tedavi sonrası CRP'de önemli düşüş gözlemişlerdir. Tedavi sonrası psoriasis hastalarında CRP düzeyinin yine kontrol grubundan önemli derecede yüksek olduğunu saptamışlardır (15). Ohtsuka ve arkadaşları psoriasisli olgularda hs-CRP düzeyinin normal kontrol grubuna göre anlamlı olarak yüksek olduğunu tespit etmişlerdir (16). Gisondi ve arkadaşları psoriasis hastalarında serum CRP düzeyini kontrol grubuna göre yüksek ve hastalık şiddeti ile korele bulmuşlardır (17). Karabudak ve arkadaşları psoriasisli hastalarda CRP düzeyinde yükselme saptamışlardır (18). İbrahimbaş ve arkadaşları psoriasis hastalarında CRP düzeyinde artışa eğilim olduğunu ve CRP ile PAŞİ arasında korelasyon olduğunu saptamışlardır (19). Pietrzak ve arkadaşları plazma hs-CRP düzeyinin psoriasis hastalarında arttığını ve tedavi ile remisyona giren hastalarda hsCRP düzeyinde düşüş olsa da, normal düzeye gelmenin söz konusu olmadığını saptamışlardır (20). Strober ve arkadaşları psoriasis ve psoriatik artritli hastalarda Etanerseptin CRP düzeyi üzerine etkilerini inceledikleri çalışmalarında psoriatik artriti olan ve olmayan tüm psoriasis hastalarında başlangıç CRP düzeyini yüksek bulmuşlardır. 12 haftalık Etanersept tedavisi sonrası serum CRP düzeyinde önemli ölçüde düşüş gözlemlemişlerdir (3).

Bizim çalışmamızda CRP değerleri psoriasis hastalarında $(n=128)$ kontrol grubuna $(n=98)$ göre ileri derecede anlamlı yüksek bulunmuştur $(\mathrm{p}<0,001)$. Ancak psoriasis hastaları arasında CRP değerleri ile PAŞİ değerleri arasında anlamlı bir ilişki bulunmamıştır ( $p=0,093)$. Bizim gibi PAŞİ ve CRP arasında ilişki saptamayan çalışmalar da literatürde mevcuttur.

Emre ve arkadaşları PAŞİ değerleri ile CRP $(p=0,562)$ ve hs-CRP seviyeleri arasinda $(p=0,901)$ anlamlı bir ilişki saptamamışlardır (21). Sergeant ve arkadaşları hs-CRP düzeyinin püstüler psoriasiste daha yüksek olduğunu bulmuşlardır. Aynı çalışmada PAŞİ değerleri ile hs-CRP düzeyleri arasında anlamlı bir ilişki bulamamışlardır (22). Bozkurt ve arkadaşları yapılan tüm çalışmalar ve bizim çalışmamızın aksine CRP değerleri açısından kontrol grubuyla anlamlı fark saptamamışlardır. Ancak yine bizim çalışmamızın aksine PAŞI ile CRP değerleri arasında pozitif yönde güçlü bir ilişki saptamışlardır (23).

Laurent ve ark. artriti olmayan psoriasis hastalarında, şiddetli hastalık durumunda bile CRP düzeylerinde anlamlı bir yükselme olmadığını gözlemlemişlerdir (24). Balcı ve arkadaşları da serum hs-CRP düzeyini inceledikleri çalışmalarında psoriasisli olgular ile sağlıklı kontrol bireyleri arasında anlamlı bir fark olmadığını saptamışlardır (25).

Bizim çalışmamızda ve diğer çalışmaların çoğunda, psoriasis hastalarında CRP düzeyinin kontrol grubuna göre yüksek olması psoriasisin kronik inflamatuar bir hastalık olmasının sonucudur. Ancak PAŞI ve CRP korelasyonu ile ilgili literatürde çelişkili sonuçlar mevcuttur. Biz diğer birkaç çalışmada olduğu gibi PAŞİ ve CRP'yi korele bulmadık ve buna göre, CRP'nin, komorbiditelerin eşlik etmediği plak ve guttat tip psoriasisli olgularda hastalık şiddeti farklılığını yansıtmadığ 1 sonucuna ulaştık. Bunun sebebi arada gerçekten bir korelasyon olmaması yanında çalışmamızda yer vermediğimiz PAŞİ ve CRP'yi etkileyen çeşitli etkenlerin de (hastalık süresi, klinik olarak kendini göstermeyen ancak CRP'yi etkileyen enfeksiyonlar... vs) sonucu etkilemiş olması olabilir. Ayrıca bilindiği üzere CRP primer olarak akut reaksiyonlarda yükselir. Kronik inflamasyonlarda aktivitede artış dönemlerinde yanıtın büyüklüğü klinik tabloya göre beklenenden daha az olabilir $(9,12,13)$. Psoriasis de kronik bir tablo olduğundan tablonun şiddetine göre CRP'de yeterli artış gerçekleşmemiş olabilir.

128 psoriasis hastası ve 98 kontrol bireyinden oluşan çalışmamız, Gisondi ve arkadaşlarının çalışması dışında, PAŞİ ve CRP arasında korelasyon saptayan çalıșmalardan sayısal olarak daha üstündür. Bunların dışında sayısal olarak çalışmamızdan üstün olan Chodorowska ve arkadaşları ile Strober ve arkadaşlarının çalışmalarında ise çalışmamızdan farklı olarak PAȘİ ve CRP korelasyonuna bakılmayıp, tedavi öncesi ve sonrası CRP düzeyi incelenmiştir. Ayrıca çalışmamız PAŞİ ile CRP arasında korelasyon saptamayan en yüksek sayıda hasta içeren çalışmadır.

Çalışmamızda CRP'nin psoriatik artritle ilişkisini de değerlendirdik. $\mathrm{Bu}$ yönde yapılan çeşitli çalışmalar mevcuttur.

Strober ve arkadaşları psoriatik artriti olan psoriasis hastalarında psoriatik artriti olmayanlara göre CRP düzeylerinin daha yüksek olduğunu saptamışlardır. Laurent ve ark. CRP yi psoriatik artritli olgularda anlamlı düzeyde yüksek bulmuş ve psoriatik artrit şiddeti ile CRP arasında korelasyon olduğunu saptamışlardır (24). Tam ve ark. Kardiyovasküler risk profilini inceledikleri psoriatik artrit hastalarında hsCRP düzeyini yüksek saptamıştır (26).

Biz de yapılan bu çalışmalar gibi CRP değerlerini aktif psoriatik artrit hastalarında kontrol grubuna göre 


\section{Phnx Med J. July, 2020. Volume 2 No 2}

$(\mathrm{p}<0,001)$ ve psoriasis hastalarına göre $(\mathrm{p}<0,001)$ ileri derecede anlamlı bir şekilde yüksek bulduk. Bu sonuç doğrultusunda psoriasis hastalarında sabit düzeydeki CRP'nin yükselmesinin, CRP yüksekliğine neden olacak diğer faktörler yanında psoriatik artritin de habercisi olabileceği söylenebilir.

Literatürde psoriatik artritte aktif ve inaktif dönemdeki CRP düzeylerini karşılaştıran çalışmalar da mevcuttur.

Helliwell ve arkadaşları yaptıkları çalışmada CRP'yi aktif psoriatik artritlilerde yüksek bulmuş ancak aktif ve inaktif psoriatik artritli hastalar arasında istatistiksel olarak fark saptamamışlardır (27).

Biz inaktif psoriatik artrit hastalarında da kontrol grubuna göre CRP değerlerini ileri derecede anlamlı bir şekilde yüksek bulduk ( $\mathrm{p}<0,001)$. Ínaktif psoriatik artrit hastalarında CRP düzeyi aktif psoriatik artrit hastalarından daha düşük olmasına rağmen istatistiksel olarak CRP değerleri açısından aktif psoriatik artrit hastaları ile inaktif psoriatik artrit hastaları arasında anlamlı fark bulamadik $(p=0,449)$. Bu da inaktif dönemde de olsa psoriatik artrit hastalarında inflamasyonun devam ettiğini göstermektedir.

CRP'nin psoriasis hastalarında normal popülasyona göre yüksek olmasına rağmen, hastalık şiddetiyle korele olmadığından, psoriasis şiddeti takibinde kullanımının yararlı olmayacağı; ancak psoriasis hastalarında psoriatik artrit gelişimi açısından takipte kullanılanılabileceğini düşünmekteyiz. Aktif ve inaktif psoriatik artrit hastalarında CRP düzeyi açısından anlamlı fark saptanmaması, CRP düzeyinin psoriatik artritin aktif veya inaktif dönemde olduğunu değerlendirmede tek başına yeterli bir belirteç olmadığı sonucunu doğurmaktadır.

Çıkar İlişkisi

Tüm yazarlar çıkar çatışması olmadığını beyan eder.

\section{KAYNAKLAR}

1. Gülekon A, Adışen E. Psoriasis ve Komorbiditeler. Türkderm-Deri Hastalıkları ve Frengi Arşivi Dergisi. 2008 ; 42 Özel Sayı 2: $23-25$.

2. Rocha-Pereira, P., Santos-Silva, A., Rebelo, I., Figueiredo, A., Quintanilha, A. and Teixeira, F. The inflammatory response in mild and in severe psoriasis. British Journal of Dermatology. 2004; 150: 917-928.

3. Strober B, Teller C, Yamauchi P, Miller JL, Hooper M, Yang YC, Dann F. Effects of etanercept on C-reactive protein levels in psoriasis and psoriatic arthritis. Br J Dermatol. 2008; 159: 322-30.

4. Türkoğlu Eİ, Gürgün C, Zoghi M, Türkoğlu C. Kararlı anjina pektorisi olan ve efor testi pozitif bulunan ayaktan hastalarda serum C-reaktif protein düzeyleri ile koroner arter hastalığı ile ilişkisi. Anadolu Kardiyol Derg. 2004; 4: 199-202.

5. Christophers E, Mrowietz U: Psoriasis: Fitzpatrick’s Dermatology in General Medicine. Beşinci baskı. Freedberg IM, Eisen AZ, Wolf K, Austen KF, Goldsmith AL, Katz IS, Fitzpatrick TB (eds), McGraw- Hill Inc, New York 1999:495-521.

6. K. Moen1, 2, J.G. Brun3, M. Valen3, L. Skartveit4, E.K. Ribs Eribe5, I. Olsen5,R. Jonsson1,3,6. Synovial inflammation in active rheumatoid arthritis and psoriatic arthritis facilitates trapping of a variety of oral bacterial DNAs. Clinical and Experimental Rheumatology. 2006; 24: 656663.

7. Punzi L, Pianon M, Rossini P, et al. Clinical and labaratory manifestations of elderly onset psoriatic arthritis: a comparison with younger onset disease. Ann Rheum Dis. 1999; 58:226-29.

8. Salvarani C, Macchioni P, Cremonesi T, et al. The cervical spine in patients with psoriatic arthritis: a clinical, radiological and immunogenetic study. Ann Rheum Dis. 1992;51:73-7.

9. IshakR, Hassan K: The erythrocyte sedimentation rate, C-reactive protein, plasma fibrinogen and viscosity in chronic renal disease patients with infection, Malays J Pathol. 1989;11:29-31.

10. Katz PR, Gutman SI, Richman G, Karuza J, Bartholomew WR, Baum J: Erythrocyte sedimentation rate and C-reactive protein compared in the elderly, Br J Clin Pract. 1989;43(7):252-4.

11. Kirkeby OJ, Risoe C, Vikland R: Significance of a high erythrocyte sedimentation rate in general practice, Clin Chem 1989 ;35(3):466-8.

12. Yenen O: Enfeksiyon hastalıklarında akut faz reaktanları, “Çalangu S, Eraksoy H, Özsüt H (eds): Enfeksiyon Hastalıkları '90-'91” kitabında s.21-42, Yüce Yayınları, İstanbul (1990)

13. Pincus MR, Abraham NZ: Interpreting laboratory results, "Henry JB: Clinical, LaboraticalDiagnosis andManagement by LaboratoryMethods" kitabında s.92-107, Saunders Co., Philadelphia (2001).

14. Coimbra, S., Oliveira, H., Reis, F., Belo, L., Rocha, S., et al. C-reactive protein and leucocyte activation in psoriasis vulgaris according to severity and therapy. Journal of the European Academy of Dermatology and Venereology. 2010; 24: 789-796.

15. Chodorowska, G., Wojnowska, D. and Juszkiewicz-Borowiec, M.. C-reactive protein and $\alpha_{2}$-macroglobulin plasma activity in medium-severe and severe psoriasis. Journal of the European Academy of Dermatology and Venereology. 2004; 18: 180-183.

16. Ohtsuka T. The relation between high-sensitivity c-reactive protein and maximum body mass index in patients with psoriasis. Br J Dermatol. 2008; 158: 1141-3.

17. Gisondi P, Malerba M, Malara G, Puglisi Guerra A, Sala R, Radaeli A,Calzavara-Pinton P, Girolomoni G. C-reactive protein and markers for thrombophilia in patients with chronic plaque psoriasis. Int J Immunopathol Pharmacol. 2010 Oct-Dec;23(4):1195-202.

18. Karabudak O, Ulusoy RE, Erikci AA, Solmazgul E, Dogan B, Harmanyeri Y.Inflammation and hypercoagulable state in adult psoriatic men. Acta Derm Venereol. 2008;88(4):337-40.

19. Ibrahimbaş Y, Polat M, Serin E, Parlak AH. Cellular Immune Response in Patients with Chronic Plaque Type Psoriasis: Evaluation of Serum Neopterin, Procalcitonin, Anti-Streptolysin O and C Reactive Protein Levels. J Clin Exp Dermatol Res. 2010; 1:107.

20. Pietrzak AT, Zalewska A, Chodorowska G, Krasowska D, Michalak-Stoma et al. Cytokines and anticytokines in psoriasis. Clin Chim Acta. 2008 Aug;394(1-2):7-21 


\section{Çelik et al.}

21. Emre S, Kılınç F, Demirseren D, Akyol M. Psoriasis hastalarında C-reaktif protein, yüksek sensitif C-reaktif protein ve hastalık şiddeti ilişkisi. Cumhuriyet Tip Derg. 2011; 33 (2).

22. Sergeant A, Makrygeorgou A, Chan WC, Thorrat A, Burden D. C-reactive protein in psoriasis. Br J Dermatol 2008; 158: 417-9.

23. Bozkurt NM, Yıldırım M, Ceyhan AM, Kara Y, Vural H. Investigation of Serum Visfatin Levels in Patients with Psoriasis. TURKDERM. 2010; 44(1): 15-18.

24. Laurent MR, Panayı GS, Shepherd P. Circulating immune complexes, serum immunoglobulins and acute phase proteins in psoriasis and psoriatic arthritis. Ann Rheum Dis 1981; 40: 66-9.

25. Balcı DD, Yönden Z Doğramacı ÇA, Duran N. Hafif ve orta şiddetli psoriyazis hastalarında serum yüksek sensitif c-reaktif protein ve homosistein düzeyleri. Türkderm 2009; 43: 53-7.

26. Tam LS, Tomlinson B, Chu TTW, Li M, Leung YY, Kwok LW, et al. Cardiovascular risk profile of patients with psoriatic arthritis compared to controls - the role of inflammation. Rheumatology 2008;47:718-723.

27. Helliwell PS, Marchesoni A, Peters M, Platt R, Wright V. Cytidine deaminase activity, C reactive protein, histidine, and erythrocyte sedimentation rate as measures of disease activity in psoriatic arthritis. Annals of the Rheumatic Diseases. 1991; 50: 362-365. 